\title{
BOTH GERMAN AND RUSSIAN: SECOND-GENERATION RUSSIAN-GERMAN IDENTITIES IN GERMANY*
}

\author{
Maik Hoops \\ Osnabrück University, \\ Osnabrück, Germany \\ Jannis Panagiotidis \\ University of Vienna, \\ Vienna, Austria
}

This essay presents the results of a qualitative interview study with young people of Russian-German origin born in Germany, i. e., the descendants of resettlers (Spätaussiedler) from the successor states of the former Union of Soviet Socialist Republics. Using poststructuralist theories that understand the linguistic practices and discursive attribution of social categories as modes of constituting subjectivity and corresponding identities, this study focuses on processes of natio-ethno-cultural identity formation among the second generation of Spätaussiedler and their experiences of being externally ascribed to certain natio-ethno-cultural categories. In the existing literature, this topic has been extensively addressed with regard to the first generation of Spätaussiedler, but not the second generation, whose conditions for identity formation in Germany are quite different due to their relative inconspicuousness, i. e., the invisibility of their migration background. For the first generation of Spätaussiedler, the dual exclusion as German in Russia and Russian in Germany was the cause of a persistent identity uncertainty, especially given that the labeling as "Russian" by supposed fellow Germans was perceived as a hurtful mis-ascription. The second generation, in contrast, is not subject to this dual exclusion. Surrounding society generally perceives them as German, thus reinforcing their corresponding self-identification as German. At the same time, there is a limited but positive identification with the category of Russian as well, which is less often activated by external ascriptions and rather fed by the presence of customs in the family context that are perceived as Russian.

* Citation: Hoops, M., Panagiotidis, J. (2021). Both German and Russian: SecondGeneration Russian-German Identities in Germany. In Quaestio Rossica. Vol. 9, № 3. P. 845-860. DOI 10.15826/qr.2021.3.613.

Цитирование: Hoоps M., Panagiotidis J. Both German and Russian: Second-Generation Russian-German Identities in Germany // Quaestio Rossica. Vol. 9. 2021. № 3. P. 845-860. DOI 10.15826/qr.2021.3.613.

(C) Hoops M., Panagiotidis J., 2021 Quaestio Rossica • Vol. 9 • 2021 • № 3, p. 845-860 
Members of the second generation are thus able to identify satisfactorily as both "German" and "Russian". For this generation, the evasive intermediate category "Russian-German" therefore becomes obsolete as a source of identification, while it served and still serves as a first-generation strategy for coping with dual exclusion and the resulting inability to identify as either German or Russian. At the same time, a semantic emptying and a conflation of the category "Russian-German" with the category "Russian" takes place, which results from the second generation never having perceived its own cultural otherness both as non-Russian (before migration) and non-German (after migration), but only as Russian in Germany.

Keywords: Germany, Russia, migration, identity, ascription, nationality, ethnicity, culture

Приведены результаты квалитативного исследования, включающего интервью с молодыми людьми российско-немецкого происхождения, рожденными в Германии, то есть потомками поздних переселенцев из стран бывшего СССР. Базируясь на постструктуралистских теориях, постулирующих лингвистическую практику и дискурсивную атрибуцию социальных категорий как способ конституирования субъективности и соответствующей идентичности, авторы исследования сосредоточены на процессах формирования национально-этнокультурной идентичности у второго поколения поздних переселенцев и их опыте внешней аскрипции (приписывания) к национально-этнокультурным категориям. Заявленная тема подробно освещена с точки зрения первого поколения поздних переселенцев. Второе же поколение до определенной степени было обделено вниманием исследовательского сообщества. Однако условия формирования его идентичности в Германии значительно отличались в силу не настолько ярко выраженной заметности или даже невидимости миграционного опыта второго поколения граждан российско-немецкого происхождения в обществе. Для первого поколения поздних переселенцев характерен опыт двойной эксклюзии - из-за немецкого происхождения в России и изза русского в Германии. Именно такая эксклюзия стала причиной так называемой неопределенности идентичности, особенно с учетом того, что отнесение их к категории «русских» немецкими согражданами воспринималось ими как ложная аскрипция. Второе же поколение не испытало двойной эксклюзии. Окружающее общество в целом воспринимает его представителей как немцев, тем самым усиливая и их самоидентификацию именно в этой роли. При этом они демонстрируют некоторую позитивную самоидентификацию как "русских», которая не активируется внешней аскрипцией, а поддерживается наличием в семейной среде национальных обычаев. Представители второго поколения, таким образом, могут с успехом совмещать обе идентификации. Для этого поколения неустойчивая промежуточная категория «российских немцев» как способ идентификации выходит из употребления, в то время как для первого поколения она служила и до сих пор служит стратегией преодоления двойной эксклюзии 
и происходящей из нее неспособности идентифицировать себя ни как «немцев», ни как «русских». В то же время мы видим, как семантическая категория «российских немцев» утрачивает свое значение и сливается с категорией «русских». Это обусловлено тем, что второе поколение не имеет опыта осознания своей «инородности» как не-русских (до эмиграции) и не-немцев (после эмиграции), а только лишь как русских в Германии.

Ключевые слова: Германия, Россия, миграция, идентичность, аскрипция, национальность, этническая принадлежность, культура

\author{
Whether I am Russian or German? \\ I am nothing. I am a blank page. \\ Anonymous Russian-German Spätaussiedler, $1992^{1}$ \\ I am German, you can't be more German. \\ Anonymous Second-Generation Spätaussiedler, $2014^{2}$
}

These two quotes are from two young people whose families migrated to the Federal Republic of Germany in the 1990s as so-called Spätaussiedler ${ }^{3}$ (ethnic German resettlers, literally "out-settlers") from the successor states of the Union of Soviet Socialist Republics and thus belong to a group of people commonly referred to as Russian Germans (Russlanddeutsche). Both statements were made at different points in time in the context of interviews with young Russian Germans about their natio-ethnocultural identity [Mecheril]. The question was to what extent the interviewees identify and feel (comfortable) as part of a natio-ethnocultural collective.

The first of the two quotations is, in a sense, representative of the identity problem from which many of the first-generation Spätaussiedler suffered and in some cases still suffer. Made by a young female Russian German in 1992, it succinctly illustrates the symptoms of the problem in question: the lack of ability to identify with one or more natio-ethno-cultural categories in a secure, long-term, and positive way. From this inability, feelings of (non-) belonging grew, which are unsatisfactory and sometimes very painful for those affected. Recent publications on this topic assert the no less painful permanence of this problem [Kiel, 2015, S. 72; Simonov, S. 20]. The related identity dilemma is often summed up in the phrase "In Russia we were the Germans [or the fascists], here we are the Russians," which gives voice to

1 "Ob ich Russin bin oder Deutsche? Ich bin nichts. Ich bin ein leeres Blatt" [Bruns, S. 11] (our translation).

2 "Ich bin deutsch, deutscher geht's nicht" [Graßmann, S. 38] (our translation).

${ }^{3}$ In legal terms, Spätaussiedler (or, before 1993, Aussiedler) are immigrants to Germany from Eastern Europe who are considered ethnic Germans. In this essay, the term Spätaussiedler will be used as an overarching term for those who immigrated before and after 1992. 
a fundamental insecurity about one's own identity as the result of shifting external ascriptions of belonging.

The second of the two introductory quotations, dating from 2014, stems from a person belonging to the second generation of Russian Germans in Germany, who have no transnational migration experience of their own. It seems to suggest that positive changes may have taken place with regard to the natio-ethno-cultural identity formation processes of young Russian Germans who have been born and raised in Germany. These descendants of the firstgeneration Spätaussiedler have received relatively little attention in existing research, which focuses primarily on those people of Russian-German origin who have personal experience of migration. This is partly a consequence of the fact that the bulk of research on post-Soviet Spätaussiedler was conducted from the1990s to the early 2010s, when the second immigrant generation was still mostly under-age. By now, the average time of residence of Spätaussiedler from the former Soviet Union in Germany is 22.5 years, and the second generation has come of age [Panagiotidis, S. 60].

Our study looks precisely at second-generation Russian-German Spätaussiedler in Germany. We focus on the question to what extent the identity problems of the first generation of Russian-German migrants have carried over into the second generation. Our fundamental assumption is that the biographical and life-world conditions under which the second generation is forming its identity differ substantially from those of the first generation. These changing circumstances also imply different contexts of external ascription. In theoretical terms, we draw on poststructuralist theories of linguistic practice and subject constitution, especially those of Judith Butler, which allow us to assess the effect of external ascriptions on identity formation. Based on a series of interviews with members of the second generation, we will show that the feeling of nonbelonging expressed in the first introductory quote, the feeling of insult at the mis-ascription as "Russian" by the receiving society as well as the hybrid identification as "Russian-German" (russlanddeutsch) common among the first generation, appears to be giving way to rather stable identifications as both German and Russian in the second generation.

\section{Theoretical Framework}

To operationalize our study of identity formation in the second generation, we draw on poststructuralist theories of linguistic practice and subject constitution. These allow us to assess the effect of external ascriptions on identity formation [Butler, 1997a; Butler, 1997b; Meissner, Kap. 2]. We follow a concept of identity as a person's self-conception. Thus, it is not about actual "facts" about a person, but about self-assigned descriptive, evaluative, and normative characteristics that one not only rationally perceives, but also emotionally feels as essentially shaping one's self and one's meaning in life. Understood in this way, identity thus defines an understanding of one's own role and standing in a society, which implicates one's expectations, obligations, possibilities, and limitations [Henning, S. 21, 
28-29; Korsgaard, p. 101]. Identity as a whole is a complex that emerges from the accumulation and interplay of many different partial identities. Since this paper is about national, ethnic, and cultural forms of identity, the focus is on partial identities that form social identity in distinction to personal identity, not on those that give an individual uniqueness, but on those that make an assignment to collectives [Müller, S. 14, 74].

Looking at the construction of national, ethnic, and/or cultural belonging and identity in pre-scientific and popular German discourses on migration and belonging, a diffuse, inconsistent interdependence and fusion of these three concepts can be observed [Mecheril, S. 23-24]. When talking about "Russian Germans", "Germans", and "Russians", concepts of culture, nation, and ethnicity are thought and spoken of "in a diffuse and polyvalent way" [Mecheril u. a., S. 14]. German migration scholar Paul Mecheril takes this fact into account by outlining a concept he calls "natio-ethno-cultural (multiple) belonging", under which he subsumes ethnic, national, and cultural categories [Mecheril, S. 23-24]. Since the described mixing of categories in everyday discourses becomes effective in identity constructions as well as the ascriptions of belonging examined here, in this work we label both examined identity constructions and ascribed belongings as natio-eth no-cultural.

The development of a person's natio-ethno-cultural identity can only be investigated against the background of the experiences and practices of external ascriptions of natio-ethno-cultural belonging existing in their life world. As empirical identity research proves, social partial identities in particular gain subjective meaning only by being activated through interactions in everyday life via verbally communicated ascriptions, so that they can be used for selfidentification [Müller, S. 295]. Judith Butler theorizes these findings in her poststructuralist theory. According to her, the social subject as such is first discursively created through verbally articulated ascriptions. Names, designations, and their simultaneous recognition thus form the social status of a person in the corresponding context of ascription. A person who is repeatedly referred to as a 'woman', as a 'foreigner', as a 'Russian', will (have to) assume these roles, provided that the ascriptions receive a certain degree of recognition from the outside [Butler, 1997a, p. 33-34; Butler, 1997b, p. 3-5, 84-86, 95-96]. At the same time, this person internalizes the ascriptions and develops his or her identity in reaction to them. Thereby the categories used for identification are not semantically empty labels, but historically charged with potentially infinite descriptive, evaluative, and normative connotations that give the person a sense of his or her status and roles in certain social contexts [Henning, S. 29]. By assuming and internalizing this discursively constituted social role and forming a corresponding identity, a person becomes a social being capable of social action, a subject [Butler, 1997b, p. 10-11, 84-86]. Accordingly, the subject is understood here from a poststructuralist perspective as an individual who is discursively subjected to the social structures of life and power and who, through a corresponding identity, is at the same time aware of his or her own embeddedness in these conditions and of the limits and possibilities of his or her social action. In this 
context, identity is the link between the social structure and the individual [Butler 1997b, p. 3-4; Kasap Cetingök, S. 73-74].

The importance of a subject's identity with regard to the reality of their social life also results in the subject's vulnerability. If an external attribution, which could potentially receive external recognition, contradicts one's own identity, it also calls into question the social position associated with the identity. An attribution of this kind can put the subject at risk of social relegation, resulting in a sense of vulnerability. A simple (mis-)ascription of natio-ethno-cultural belonging can be a violation, especially insofar as it can, for example, challenge the subject's indigeneity or its entitlement as a member in the context of a state or society, communicate undesirability, or marginalize it [Butler, 1997a, p. 3-4; Butler, 1997b, p. 96].

\section{The Problematic Identity of Russian Germans}

The causes of the Russian-German identity problem common in the first Spätaussiedler generation lie in the experiences of many Spätaussiedler before and after their migration to Germany [Zuhause fremd; Zuhause? Fremd?; Hier die Russen - dort die Deutschen; Rosenthal, Stephan, Radenbach; Kiel, 2009]. In the Soviet context, the Russian Germans' self-identification as German coincided with their perception by the surrounding society and the state. Ethnic identity was officially fixed in identity documents such as internal passports - the (in)famous "Fifth Point." Originally part of the Leninist agenda of leading Soviet nationalities to socialism via a strengthening of their national cultures and vernacular languages, this ascription of identity turned repressive as the Bolshevik regime began targeting particular nationalities - especially diaspora groups with outside connections - for alleged lack of loyalty [Martin, Chap. 8; Dönninghaus]. Starting from the late 1930s, Germans in the Soviet Union experienced massive repression and decades of discrimination by the state as alleged collaborators of Nazi Germany, as "fascists" and enemies of the state. The experience of collective deportation and banishment after 1941 (in the case of the Volga Germans) and 1945 (in the case of the Ukraine Germans) created a collective memory of Russian Germans as a community of fate and victimhood that was firmly linked to their German identity [Mukhina, Chap. 6] $]^{4}$. Thereby, despite all the disparagement by the majority in Soviet society, a positive self-esteem and sometimes elitist self-image as virtuous, modest, clean, hardworking, and religious evolved. Analogously, aversion to and dissociation from the category "Russian" grew, which was perceived as contrary to one's own positive self-image. The resulting feelings of not belonging in the USSR also activated desires for a 'return' to a - mostly imagined - German homeland [Kiel, 2015, S. 79-80; Hilbk, S. 63-64; Armborst]. At the same time, the shift from German to Russian

\footnotetext{
${ }^{4}$ According to Rosenthal, Stephan, and Radenbach, this collective narrative of suffering also served to gloss over other experiences, especially the Ukraine Germans' actual association with Germany and Nazism during the German occupation of Ukraine, including involvement in the Holocaust. About the complex memory of these events see: [Petersen].
} 
as the primary language of communication and rising rates of interethnic marriages led to widespread processes of cultural assimilation [Mukhina, Chap. 6]. However, the institutionalized nature of ethnicity in the Soviet Union prevented full-scale assimilation [Brubaker].

The prospect of actual emigration to the Federal Republic of Germany, which became realistic from the mid-1980s due to the opening-up of the USSR during perestroika and the subsequent collapse of the socialist system, awakened for many Russian Germans the strong hope of escaping their status as a natio-ethno-cultural minority so often viewed with suspicion and disdain, and to be received as equals by their peers in the 'true homeland', as "Germans among Germans." However, these hopes were suddenly dashed after the arrival of millions of Spätaussiedler in Germany. In addition to the unsettling self-perception of their own otherness in comparison to the Germans living in the Federal Republic (the German Germans, as we shall also call them), the experience of being perceived and called "Russian" by these very same people shook the hitherto undoubted and proudly borne German identity of many of the Spätaussiedler. German Germans thus not only refused to recognize Russian Germans as fellow Germans, but assigned them to the Russian "other," causing a fundamental and continuing identity uncertainty [Kiel, 2015, S. 7-76, 86-87; Simonov, S. 167, 177].

One coping mechanism with the identity problems described above was the widespread identification as "Russian-German" among post-Soviet Spätaussiedler, which prevailed over the pre-migration identification as simply "German." For many Russian Germans no longer able to identify themselves as "German" without reservation, the category "RussianGerman" seemed to describe what had shaped their life and family history as a whole: continued minority status, the double experience of exclusion, the ascription by the majority society as "German" and thus foreign and as "Russian" and thus also foreign after migration to Germany. Being German in the Russian perception and Russian in the German-German perception, and not being accepted by either side as fully belonging, suggested to Russian-German migrants that they had a relationship to both groups in their everyday lives, but nevertheless did not really belong to either side. The category "Russian-German" seems to have been activated on the one hand as a partly Russian, partly German hybrid, but on the other as a last resource of identification, delimited from both sides. It is an evasive category, as it were, that has been activated by the fact that the contradictory external ascriptions on the part of the majority society of Soviet Russia and Federal Germany conveyed a non-affiliation on both sides. This reveals the post-migration retrospectivity in RussianGerman identity, which had much less importance in the earlier thinking of the "Germans in Russia" than it would have had in the decades after migration [Kiel, 2015, S. 76-79] $]^{5}$.

\footnotetext{
${ }^{5}$ About the persistent irrelevance of the label "Russian German" among ethnic Germans who stayed in Russia, see: [Flack, S. 441].
} 
The conditions of identity formation among the second generation of Russian Germans, i. e., the descendants of post-Soviet Spätaussiedler who have been born and raised in Germany, differ substantially from those of the first generation. They have not personally experienced the transnational migration process, which makes identity more vulnerable in any case, and were less influenced by the accompanying symptoms of this migration process. They did not have to experience the sudden loss of most of their mostly Russian-influenced - social environment, nor did they have to cope with culture shock, nor with communication problems in German society because of their inadequate knowledge of the German language. They never experienced double exclusion in form of a minority status before and after migration, let alone discrimination and violence by the Soviet system. They were not referred to as Germans by a Russian-dominated environment for a large part of their lives, and then suddenly and surprisingly re-assigned to the natio-ethno-cultural category "Russian" by the Germans in Germany.

The second generation of Spätaussiedler is also "invisible" in German society to a much greater extent than the first generation. With regard to the latter, research shows that the use of the Russian language, a Russian accent in German, or certain deviating fashionable habits, for instance, led German Germans to label Spätaussiedler as "Russian" [Bruns, S. 12; Hilbk, S. 64; Kiel, 2015, S. 75; Kurilo, S. 63]. These forms of habitual conspicuousness in a natio-ethno-cultural sense, which in Germany often serve as a motivation for attributing people to non-German categories, are much less effective in the second generation. Instead, members of the second generation are presumably perceived as German to a greater extent and labeled accordingly, since they correspond more closely to the "habitual fiction of the natio-ethno-cultural prototype" of the German [Mecheril, S. 28]. In the overall analysis, the conditions under which the second generation is forming its natio-ethno-cultural identity appear to be more conducive to satisfactory identity formation.

\section{The Empirical Study}

Against this theoretical background, we conducted four guideline-based individual interviews in German with four 19- to 21-year-old individuals, all of whom belong to the second generation of Russian-German Spätaussiedler [Kruse, S. 203-204]. They were given the following pseudonyms, which were selected according to the frequency and (natio-ethno-cultural) peculiarity of their actual names: Regina $\left({ }^{\star} 1998\right)$, Sebastian $\left({ }^{\star} 1999\right)$, Louis $\left({ }^{\star} 1997\right)$, and Anna $\left({ }^{\star} 1997\right)$. They all spent most of their childhood and youth in Lower Saxony, in the suburban southern or eastern environs of Bremen and thus in regions with fairly average post-Soviet Spätaussiedler population density by Lower Saxon standards [Panagiotidis, S. 94]. At the time of the interviews, the subjects were all employed as apprentices or attended school. They all belong to the Protestant denomination. They all have Russian-German parents and ancestors, with different degrees of ethnic "mixing": Regina has a Russian-German father and a Russian mother; Anna has two Russian- 
German grandfathers and two Russian grandmothers; Louis has only Russian-German ancestors; and Sebastian has a German-German father and a Russian-German mother. While Louis' parents migrated to Germany between 1972 and 1975 when they were still children, the parents of the other subjects moved to Germany as young adults between 1989 and 1996 . Regina's parents come from Kyrgyzstan, while Louis' and Anna's parents and Sebastian's mother are from Kazakhstan. Only Anna and Regina speak some Russian, while Louis and Sebastian only understand a few words.

While obviously not representative in any statistical sense, this sample of young people can be considered typical for Russian Germans in Germany in several regards. They share their small-town origins with the vast majority of post-Soviet Spätaussiedler, some 77 percent of whom live in towns and cities with fewer than 100,000 inhabitants - a percentage that is slightly higher than among the "native" population, and significantly higher than among the overall immigrant population [Panagiotidis, S. 95]. While representative statistical data on the educational achievements of the second generation is lacking, the interviewees' educational trajectories also appear fairly typical in the sense that they completed or were on their way to completing a high school certificate (Abitur) or second-tier degree (Realschulabschluss), but do not attend university [Ibid., S. 63]. Like the majority of Russian Germans, they are Protestants - however, not of the evangelical kind, which is widespread but by no means majoritarian among Spätaussiedler in Germany [Ibid., S. 196]. Their limited or non-existent knowledge of Russian is also a widespread phenomenon among their generation, given that their parents often consciously chose not to pass it on to their children in order to help their assimilation as Germans [Ibid., S. 120-122]. Their life worlds are thus in many ways representative of the experience of many of their peers.

In the interviews, a series of openly/deductively formulated questions was used to try to manifest the developmental processes of the subjects' natio-ethno-cultural identities over the course of their lives, depending on the influencing factor of their experiences of being externally ascribed to certain natio-ethno-cultural groups. In addition, the respondents were asked to explain the connotations they associate with the respective natioethno-cultural categories of their identification and experienced external ascriptions. Moreover, they also had to evaluate their experiences of external ascription and their processes of identity formation in terms of the feelings and sensations that those triggered in them.

All respondents indicated "German" as the natio-ethno-cultural category with which they identify most strongly, though in most cases not exclusively. Except for Louis, for whom "German" is the only natio-ethno-cultural category with which he identifies ("We are Germans!"), the others also name at least one other category. In Regina's case, the Russian component is roughly equal to her German identity ("I see myself as this and also that!"). Anna identifies herself not only as "German" but also as "Russian" ("partly this, partly that, but if I had to choose, then German"). Sebastian identifies himself as "mainly simply German, but also a lot of 'Russian"'; on explicit request 
he describes "a kind of connection" to the category "Russian-German," whereas the others negate this category as a source for identification. With the exception of Anna, who expresses uncertainties about her identity ("But yes, you just don't really know what you are"), all of the test subjects showed themselves to be quite secure and satisfied in their identities.

Looking at the interviewees' experiences of external ascription of natioethno-cultural belonging, we see that the categories of ascription roughly match the categories of their respective self-identifications. The ascription as "German" seems to be the most common and predominant outside the family space in most everyday contexts. Ascriptions as "Russian" are experienced to a much lesser extent by the test persons. Louis reports that hardly anyone perceives him as Russian and sometimes other people even express astonishment when he talks about his parents' origins: "And then the reaction usually is: Really? You look like a German." When asked about the categories others identify him with, Sebastian simply answered: "Also as 'German', quite normal." Anna also sees a predominance of the external perception of her as "German": "Yes, for most people I am rather German, I would say. At least that's what most people tell me, that they tend to see me as German and often forget that I, my parents, or my family are Russian." Regina, on the other hand, describes a somewhat greater presence of the external ascription "Russian":

Yes, most of the time it is the case that people in Germany tend to see you as a Russian and when you are in Russia, I would say, you are more likely to be seen as German. Okay, maybe some people say that I am German because I was born here, but there are also those who say 'Well, you have Russian roots, you are more Russian'...

However, this ascription as Russian in Germany seems to occur when she talks about her parents' origins in the USSR. In contrast to this, members of the first generation mostly report that they are perceived as Russian because of their accent or other noticeable features, without having made any statement about their origin. Our interviewees are not "visible" in the same way, as Louis explains:

I also look completely like a German, don't I? There's nothing Russian about me, I have no accent, nothing, and they just see me that way. So no one has ever come to me and asked: 'Hey, are you Russian?'

The dominant self-identification of our interviewees as "German", which seems satisfying and unproblematic, is thus in agreement with the external ascription on the part of the "native" German population. Since the test subjects give their environment hardly any indications of a non-German origin in the form of habitually visible otherness, they see themselves confirmed by the predominant external ascription as "German" by the German Germans. 
Despite the predominant identification as German, the subjects in the interviews repeatedly directed the focus of conversation to the category "Russian" and explained in detail the importance in their families of the Russian language, Russian food, and Russian festivities. While Russian identity is explained through the presence of Russian cultural elements in family life, German identity is primarily explained through the absence of Russian cultural elements in most extra-familial contexts. The fact that the category "Russian" became the central topic of discussion may be due to the fact that the test subjects were interviewed as Russian Germans and therefore believed that the focus on "Russian" topics fulfilled the expectations of the interviewer. German identity, on the other hand, seems to be perceived as something like a "normal state" that requires no explanation and is not worth talking about. The collective narratives of victimhood and pride which the parent and grandparent generations associated with their German identity apparently has no significant meaning for our interviewees. The fact that they understand being German as natio-ethnocultural non-difference from the fictitious German prototype indicates an assimilation of their understanding of being German to the meaning of the category "German" that prevails in Federal German society, and a shift away from the understanding of the older generations.

The rather subordinate identification with the category "Russian", which applies to three out of four interviewees and is activated byless frequent external ascriptions, seems to play a less significant but rather positive role in the lives of the test subjects. Compared to the first generation, the more positive and relaxed identification with the category "Russian" seems to be possible at all because the test subjects have never themselves experienced discrimination and repression based on their German origin in a Russian-dominated Soviet environment. In their personal life world, this generation has never found itself in longtime opposition to a Russian majority. Instead, certain cultural practices cultivated within their own families appear to be Russian in comparison to German-dominated society. Since the sample has a positive emotional attachment to these family-related cultural customs perceived as Russian, a certain positive self-perception as Russian is promoted. Anna even explains that she is "perhaps a little proud" of her Russian identity. The test subjects define the category "Russian" primarily through cultural elements that they perceive as Russian and not with reference to origin - despite the fact that two out of the four do have partly Russian ancestry. Sebastian mentions "Russian food, Russian language, Russian music, Russian culture." With regard to family life, Anna describes "that this is always very strong with Russians and I can confirm this, that everyone stands behind everyone, that we see each other often, meet often." Pejorative conceptions of the category "Russian" that prior generations might have held have apparently hardly been transported into this generation.

Although three of the four test persons tend to identify positively with the category "Russian", a certain dissatisfaction with its external ascription is still evident in some cases. Louis, for instance, who does not identify as 
Russian, comments with a laugh that "among my best friends I am often referred to as, yes, the Russian, but I don't mind, I know exactly why they say that or something else." Here it appears that an external identification as "Russian" could be perceived as pejorative if attributed seriously or by people who are not close. Anna describes the feeling that people who perceive her as Russian "then think a little more negatively about me." Regina muses that many people associate "Russian" with "something negative." Only Anna refers to a stronger identity-confusing effect of the external ascription "Russian":

I always find that a bit strange or unpleasant, because some people say 'Yes, you are this', others say 'that', but when friends say something like that, for example, I think they don't have the slightest idea anyway, so it's a bit difficult. But yes, you just don't really know what you are, tha"s the thing. $\langle\ldots\rangle$ For example, my dad once said 'Yes, you are not really Russian, you are completely German', because I was born in Germany. Then I hear from others 'No, you are Russian, you have Russian parents'. So that completely throws you off, well, not off track, but it just confuses you and you don't know who you are, especially since you were born in Germany and your parents can also speak Russian. I mean, then you can't be German, but you actually have something to do with Russian culture or identity.

Anna's case shows an insecurity about her identity that on the face of it appears very similar to that of the first generation. It manifests in doubts about her own natio-ethno-cultural belonging that arise from the different coexisting ascriptions she perceives as to some extent contradictory. In contrast to the first generation, however, this problem does not seem to be so severe for Anna that it makes it impossible for her to identify as German or Russian, as we saw above. As a consequence, the category "Russian-German" has little appeal to her as a source of identification, despite her awareness of a particular Russian-German history. Describing her measure of identification with that category, she states:

I would even say less, because that doesn't play a big role for us, because that's just my grandpa, or my two grandpas who are Russian Germans and because my parents and the rest of the family were born in Kazakhstan, they feel more Russian. Of course, they were called 'German', thus as 'those Germans' [through her tone she emphasizes the pejorative character of this ascription], so they were called 'German', because their dad is from Germany, but I wouldn't really identify with Russian Germans. Well, I don't know how to explain this, it's more of a Russian thing. I wouldn't actually know where to draw the line there.

Anna is not alone with her difficulty in drawing a clear line between "Russian" and "Russian-German." Both Regina and Sebastian stated that they are hardly able to distinguish between those categories or to define any peculiarities of the category "Russian-German", while Louis seemed to fully 
equate "Russian" and "Russian-German". Thus, in addition to becoming obsolete as an intermediate category of identification, "Russian-German" is also experiencing semantic emptying and assimilation into the category "Russian". Since the second generation never had to perceive an otherness in themselves that appeared to be German in contrast to a Russiandominated majority, but instead perceived their very rarely visible natioethno-cultural conspicuousness as rather Russian in comparison to the German-German majority, a fading of the category Russian-German seems logical, since it was fed by a dual experience of foreignness. The blurring of the supposedly very clear line between "Russian Germans" and "Russians" mitigates the incipient identity conflict that became apparent in Anna's previous statement: rather than being a clear mis-ascription, her labelling as Russian refers to a category of identification that is actually relevant for her. It points to a simultaneous inclusion in two natio-ethno-cultural collectives that may appear contradictory in an exclusivist logic, but can be more easily reconciled than a dual exclusion as German in Russia and Russian and Germany.

Our interviews have shown that young people of the second generation of Russian-German Spätaussiedler are increasingly developing positive and satisfactory German identities, which are confirmed and strengthened by the majority society's external ascription as German. In this context, being German means being a recognized and natio-ethno-culturally inconspicuous part of German-majority society. Neither the often descentoriented and sometimes elitist ideas of being German nor the collective identity narratives centered on victimhood and suffering which existed in USSR before migration have been passed on to a significant extent. At the same time there is limited, but positive identification as Russian. This is less frequently activated by external ascriptions because origin from the former USSR is less obvious. Russian language skills are also receding in the second generation. To a certain extent, Russian identity is fed by what is perceived as "Russian" in the family context. The category "RussianGerman," by contrast, is hardly ever used for identification. Since the second generation is able to identify satisfactorily as both "German" and "Russian," the intermediate category "Russian-German" becomes obsolete as a source for identification and experiences a semantic emptying in the consciousness of the second generation. The traumatizing pre- and postmigrant historical experiences of earlier generations of Russian Germans and their self-image as a doubly excluded minority have only marginally shaped the consciousness of the second generation and no longer serve as the central pillar of a fading natio-ethno-cultural category "RussianGerman" in the context of identity formation of young Russian Germans. They were not "there the Germans and here the Russians" - they are both here the Germans and, to some extent, here the Russians. 


\section{Список литературы}

Armborst K. Ablösung von der Sowjetunion : Die Emigrationsbewegung der Juden und Deutschen vor 1987. Münster : LIT, 2001. 464 S.

Brubaker R. Nationhood and the National Question in the Soviet Union and Post-Soviet Eurasia: An Institutionalist Account // Theory and Society. 1994. № 23. P. 47-78. DOI 10.1007/BF00993673.

Bruns I. „Manchmal bin ich nichts“: Gespräche jugendlicher Aussiedler aus Polen und Rußland. Reutlingen : Verlagswerk der Diakonie, 1992. 77 S.

Butler J. Excitable Speech: A Politics of the Performative. N. Y. ; L. : Routledge, 1997a. 200 p.

Butler J. The Psychic Life of Power: Theories in Subjection. Stanford : Stanford Univ. Press, 1997b. 228 p.

Dönninghaus $V$. Minderheiten in Bedrängnis: sowjetische Politik gegenüber Deutschen, Polen und anderen Diaspora-Nationalitäten 1917-1938. München : R. Oldenbourg, 2009. 693 S.

Flack A. Zugehörigkeiten und Esskultur : Alltagspraxen von remigrierten und verbliebenen Russlanddeutschen in Westsibirien. Bielefeld : Transcript. 2020. 500 S.

Graßmann W. Deutsch, deutscher geht's nicht // Praxis Geschichte. 2015. Heft 4. S. 38-41.

Henning T. Personale Identität und personale Identitäten - Ein Problemfeld der Philosophie // Identität: Ein Kernthema moderner Psychotherapie - interdisziplinäre Perspektiven / Hrsg. von H. Petzold. Wiesbaden : VS Verlag für Sozialwissenschaften, 2012. S. 19-38.

Hier die Russen - dort die Deutschen : Über die Integrationsprobleme russlanddeutscher Jugendlicher 250 Jahre nach dem Einladungsmanifest von Katharina II / Hrsg. von M. Hermann, R. Öhlschläger. Baden-Baden : Nomos, 2013. 120 S.

Hilbk M. Trauma und Traum: Russlanddeutsche auf der Suche nach Heimat und Identität // Entwurzelung - Bindung - Transformation / Hrsg. von B. Nielsen. Heidelberg : Mattes, 2014. S. 63-72.

Kasap Cetingök Y. Zur Konstruktion der kulturellen Identität und ihrer Anerkennung unter poststrukturalistischer Sicht : Kontingenz des Politischen und Subjektiven // Kulturen der Bildung. Kritische Perspektiven auf erziehungswissenschaftliche Verhältnisbestimmungen / Hrsg. von M. Hummrich, N. Pfaff, I. Dirim, C. Freitag. Wiesbaden : Springer VS, 2016. S. 67-76.

Kiel S. Wie deutsch sind Russlanddeutsche? Eine empirische Studie zur ethnisch-kulturellen Identität in russlanddeutschen Aussiedlerfamilien. Münster : Waxmann, 2009. 216 S.

Kiel S. Heterogene Selbstbilder: Identitätsentwürfe und -strategien bei russlanddeutschen (Spät-)Aussiedlern // Zuhause? Fremd? Migrations- und Beheimatungsstrategien zwischen Deutschland und Eurasien / Hrsg. von M. Kaiser, M. Schönhuth. Bielefeld : Transcript, 2015. S. 73-89.

Korsgaard C. The Sources of Normativity. Cambridge : Cambridge Univ. Press, 1996. 290 p. Kruse J. Qualitative Interviewforschung: Ein integrativer Ansatz. $2^{\text {nd }}$ Ed. Weinheim : Beltz Juventa, 2015. $708 \mathrm{~S}$.

Kurilo O. Russlanddeutsche als kulturelle Hybride. Schicksal einer Mischkultur im 21. Jahrhundert // Zuhause? Fremd? Migrations- und Beheimatungsstrategien zwischen Deutschland und Eurasien / Hrsg. von M. Kaiser, M. Schönhuth. Bielefeld : Transcript, 2015. S. 53-72.

Martin T. The Affirmative Action Empire: Nations and Nationalism in the Soviet Union, 1923-1939. Ithaca : Cornell Univ. Press, 2011. 528 p.

Mecheril $P$. Prekäre Verhältnisse: Über natio-ethno-kulturelle (Mehrfach-) Zugehörigkeit. Münster : Waxmann, 2003. 233 S.

Mecheril P. u. a. Migrationspädagogik. Weinheim ; Basel : Beltz, 2010.192 S.

Meissner H. Jenseits des autonomen Subjekts: Zur gesellschaftlichen Konstitution von Handlungsfähigkeit im Anschluss an Butler, Foucault und Marx. Bielefeld : Transcript, 2010.303 S. 
Mukhina I. The Germans of the Soviet Union. N. Y. : Routledge, 2007. 240 p.

Müller B. Empirische Identitätsforschung: Personale, soziale und kulturelle Dimensionen der Selbstverortung. Wiesbaden : VS Verlag für Sozialwissenschaften, 2011. $416 \mathrm{~S}$.

Panagiotidis J. Postsowjetische Migration in Deutschland: eine Einführung. Weinheim : Beltz Juventa, 2021. $246 \mathrm{~S}$.

Petersen H. Selektive Erinnerung. Der Zweite Weltkrieg in der Ukraine im historischen Gedächtnis der Russlanddeutschen // Holocaust Studies : A Ukrainian Focus. 2019. Vol. 11. P. 207-237.

Rosenthal G., Stephan V., Radenbach N. Brüchige Zugehörigkeiten: Wie sich Familien von „Russlanddeutschen“ ihre Geschichte erzählen. Frankfurt a/M : Campus, 2011. 287 S.

Simonov $N$. Die heimatlosen Heimkehrer: Zwei Subkulturen im Vergleich. Sozialpsychologische Aspekte der Identität von russlanddeutschen Spätaussiedlern in Deutschland und irischen Heimkehrern in Irland. Hamburg : Dr. Kovač, 2013. 352 S.

Zuhause fremd: Russlanddeutsche zwischen Russland und Deutschland / Hrsg. von S. Ipsen-Peitzmeier, M. Kaiser. Bielefeld : Transcript, 2006. 430 S.

Zuhause? Fremd? Migrations- und Beheimatungsstrategien zwischen Deutschland und Eurasien / Hrsg. von M. Kaiser, M. Schönhuth. Bielefeld : Transcript, 2015. 416 S.

\section{References}

Armborst, K. (2001). Ablösung von der Sowjetunion: Die Emigrationsbewegung der Juden und Deutschen vor 1987. Münster, LIT. 464 S.

Brubaker, R. (1994). Nationhood and the National Question in the Soviet Union and Post-Soviet Eurasia: An Institutionalist Account. In Theory and Society. No. 23, pp. 47-78. DOI 10.1007/BF00993673.

Bruns, I. (1992). "Manchmal bin ich nichts ": Gespräche jugendlicher Aussiedler aus Polen und Rußland. Reutlingen, Verlagswerk der Diakonie. $77 \mathrm{~S}$. $200 \mathrm{p}$.

Butler, J. (1997a). Excitable Speech: A Politics of the Performative. N. Y., L., Routledge.

Butler, J. (1997b). The Psychic Life of Power: Theories in Subjection. Stanford, Stanford Univ. Press. 228 p.

Dönninghaus, V. (2009). Minderheiten in Bedrängnis: sowjetische Politik gegenüber Deutschen, Polen und anderen Diaspora-Nationalitäten 1917-1938. München, R. Oldenbourg. $693 \mathrm{~S}$.

Flack, A. (2020). Zugehörigkeiten und Esskultur: Alltagspraxen von remigrierten und verbliebenen Russlanddeutschen in Westsibirien. Bielefeld, Transcript. $500 \mathrm{~S}$.

Graßmann, W. (2015). Deutsch, deutscher geht's nicht. In Praxis Geschichte. Heft 4, S. 38-41.

Henning, T. (2012). Personale Identität und personale Identitäten - Ein Problemfeld der Philosophie. In Petzold, H. (Hrsg.). Identität: Ein Kernthema moderner Psychotherapie interdisziplinäre Perspektiven. Wiesbaden, VS Verlag für Sozialwissenschaften, S. 19-38.

Hermann, M., Öhlschläger, R. (Hrsg.). (2013). Hier die Russen - dort die Deutschen: Über die Integrationsprobleme russlanddeutscher Jugendlicher 250 Jahre nach dem Einladungsmanifest von Katharina II. Baden-Baden, Nomos. $120 \mathrm{~S}$.

Hilbk, M. (2014). Trauma und Traum: Russlanddeutsche auf der Suche nach Heimat und Identität. In Nielsen, B. (Hrsg.). Entwurzelung - Bindung - Transformation. Heidelberg, Mattes, S. 63-72.

Ipsen-Peitzmeier, S., Kaiser, M. (Hrsg.) (2006). Zuhause fremd: Russlanddeutsche zwischen Russland und Deutschland. Bielefeld, Transcript. $430 \mathrm{~S}$.

Kaiser, M., Schönhuth, M. (Hrsg.). (2015). Zuhause? Fremd? Migrations- und Beheimatungsstrategien zwischen Deutschland und Eurasien. Bielefeld, Transcript. 416 S.

Kasap Cetingök, Y. (2016). Zur Konstruktion der kulturellen Identität und ihrer Anerkennung unter poststrukturalistischer Sicht: Kontingenz des Politischen und Subjektiven. In Hummrich, M., Pfaff, N., Dirim, I., Freitag, C. (Hrsg.). Kulturen der 
Bildung. Kritische Perspektiven auf erziehungswissenschaftliche Verhältnisbestimmungen. Wiesbaden, Springer VS, S. 67-76.

Kiel, S. (2009). Wie deutsch sind Russlanddeutsche? Eine empirische Studie zur ethnisch-kulturellen Identität in russlanddeutschen Aussiedlerfamilien. Münster, Waxmann. $216 \mathrm{~S}$.

Kiel, S. (2015). Heterogene Selbstbilder: Identitätsentwürfe und -strategien bei russlanddeutschen (Spät-)Aussiedlern. In Kaiser, M., Schönhuth, M. (Hrsg.). Zuhause? Fremd? Migrations- und Beheimatungsstrategien zwischen Deutschland und Eurasien. Bielefeld, Transcript, S. 73-89.

Korsgaard, C. (1996). The Sources of Normativity. Cambridge, Cambridge Univ. Press. 290 p.

Kruse, J. (2015). Qualitative Interviewforschung: Ein integrativer Ansatz. $2^{\text {nd }}$ Ed. Weinheim, Beltz Juventa. $708 \mathrm{~S}$.

Kurilo, O. (2015). Russlanddeutsche als kulturelle Hybride. Schicksal einer Mischkultur im 21. Jahrhundert. In Kaiser, M., Schönhuth, M. (Hrsg.). Zuhause? Fremd? Migrations- und Beheimatungsstrategien zwischen Deutschland und Eurasien. Bielefeld, Transcript, S. 53-72.

Martin, T. (2001). The Affirmative Action Empire: Nations and Nationalism in the Soviet Union, 1923-1939. Ithaca, Cornell Univ. Press. 528 p.

Mecheril, P. (2003). Prekäre Verhältnisse: Über natio-ethno-kulturelle (Mehrfach-) Zugehörigkeit. Münster, Waxmann. 233 S.

Mecheril, P. et al. (2010). Migrationspädagogik. Weinheim, Basel, Beltz. 192 S.

Meissner, H. (2010). Jenseits des autonomen Subjekts: Zur gesellschaftlichen Konstitution von Handlungsfähigkeit im Anschluss an Butler, Foucault und Marx. Bielefeld, Transcript. $303 \mathrm{~S}$.

Mukhina, I. (2007). The Germans of the Soviet Union. N. Y., Routledge. 240 p.

Müller, B. (2011). Empirische Identitätsforschung: Personale, soziale und kulturelle Dimensionen der Selbstverortung. Wiesbaden, VS Verlag für Sozialwissenschaften. $416 \mathrm{~S}$.

Panagiotidis, J. (2021). Postsowjetische Migration in Deutschland: eine Einführung. Weinheim, Beltz Juventa. 246 S.

Petersen, H. (2019). Selektive Erinnerung. Der Zweite Weltkrieg in der Ukraine im historischen Gedächtnis der Russlanddeutschen. In Holocaust Studies: A Ukrainian Focus. Vol. 11, pp. 207-237.

Rosenthal, G., Stephan, V., Radenbach, N. (2011). Brüchige Zugehörigkeiten: Wie sich Familien von ,Russlanddeutschen “ ihre Geschichte erzählen. Frankfurt a/M, Campus. $287 \mathrm{~S}$.

Simonov, N. (2013). Die heimatlosen Heimkehrer: Zwei Subkulturen im Vergleich. Sozialpsychologische Aspekte der Identität von russlanddeutschen Spätaussiedlern in Deutschland und irischen Heimkehrern in Irland. Hamburg, Dr. Kovač. 352 S.

The article was submitted on 25.01.2021 